\title{
Traditional irrigation in the shaping of cultural landscapes. The case study of Tricarico, Southern Italy.
}

\author{
Antonio Graziadei \\ Independent researcher \\ agraziadei@woplab.it
}

\begin{abstract}
The paper presents the case study of Tricarico, its gardens and its traditional irrigation systems. In Tricarico the interaction between man and environment has been enriched in the centuries by the contribution of different cultures, amongst which the Arab and Hebrew ones. In this town elaborate techniques of catching and managing of water and soils, in association with complex irrigation systems, have given form to a cultural landscape of great interest. It is possible to recognise at least two different typologies of irrigated agricultural areas. A first one exploits the waters that are diverted from a central stream, then subdivided and led to the fields or to storage basins by means of a complex distribution systems. Another group of vegetable gardens is located at the bottom of the valley by the feet of the Saracena quarter. This agricultural area is articulated on terracings that degrade toward the stream. The irrigation of this second typology of vegetable gardens is provided by the water naturally drained by the rock and stored in some masonry cisterns. A net of open air and underground canals leads the water from these cisterns to the cultivated zones only by means of gravity. The techniques and the knowledge at the base of the operation of the gardens of Tricarico, passed by generations and adapted to the present times, keep on transforming the human demands and the natural resources into cultural heritage.
\end{abstract}

Keywords: Traditional irrigation systems; Cultural landscapes; Traditional knowledge; Southern Italy; Tricarico.

\section{Introduction}

Object of this paper are the agricultural areas in the immediate vicinity of the town of Tricarico and, in particular, the irrigation and management systems of cultivated areas. Tricarico is a town in the inner southern Italian Basilicata region (fig. 1) in which the interaction between human activities and natural resources has produced a landscape characterised by a close relationship between the inhabited area and the agricultural area that grows just outside of it. Entire generations, over the centuries, have shaped the spaces of the city life and those of the agricultural life making each other inseparable and part of a landscape that is both urban and rural at the same time.

The production areas subject of this contribution are characterised by an articulated network of vegetable gardens and orchards whose existence is based on careful soil management and control techniques for the collection and distribution of water through the only use of the force of gravity. From their geo-morphological and topographical characteristics, it is possible to identify different types of cultivated spaces, each associated with specific crops and irrigation systems.

The gardens of Tricarico were previously cited as examples of the ability to transform the environment for productive purposes ${ }^{1}$ or as evidence of the Arab presence in Tricarico ${ }^{2}$. An initial, partial analysis of the structures and their function in relation to the village by

\footnotetext{
1 Laureano 1988: 108-9.

2 Biscaglia 1999-2000: 112; Biscaglia 2012: 77-95.
} 
the author ${ }^{3}$ was followed by a study aimed at drafting an environmental improvement project drawn up by the University of Basilicata ${ }^{4}$. In the framework of a revaluation project, a research on the plant species introduced by the Arabs in Tricarico and Basilicata was also conducted ${ }^{5}$.

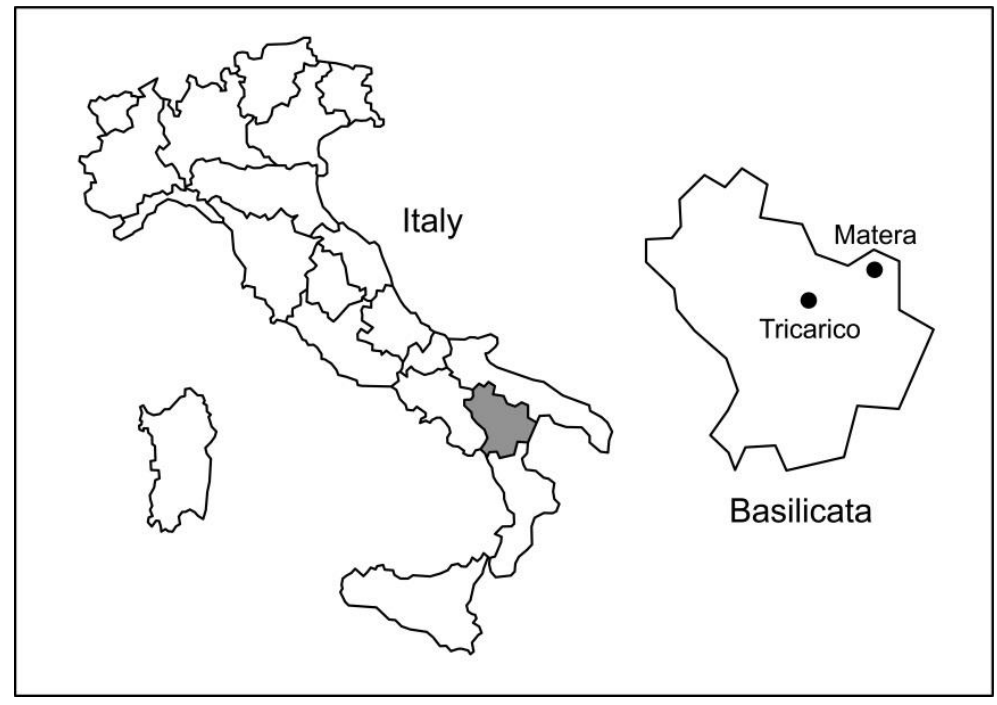

Fig. 1. The Basilicata region and Tricarico.

The objective of this paper is to provide a detailed description of the current state of the agricultural production area, the irrigation systems contained therein and some of the structures that constitute them. A reconstruction of the water collection and distribution systems in irrigated areas, as well as the traditional knowledge and practices underlying the creation and management of agricultural spaces, has also been attempted, where possible. An additional objective is that of investigating whether the organisation of these agricultural production areas can actually be put in relation with some of the ethnic and cultural groups, in particular the Arab and Berber ones, who have settled in Tricarico over the centuries.

\section{Physical space and historical sources}

The historic centre of Tricarico is spread over calcareous spur in north-south direction, at an average altitude of about $670 \mathrm{~m}$ above sea level. The stream Cacarone flows to its west, originating in the Conca (Valley) of Sant'Antonio ${ }^{6}$ and heading north, where it joins the stream Milo. The Cacarone Valley, initially a mild and wide depression to the southwestern outskirts of the town, quickly narrows and deepens along the stream, becoming a sort of deep canyon between the bedrock on which Tricarico stands and another hill, also calcarenitic, to the west. At the point where the two streams join, the height difference between them and the town is about $110 \mathrm{~m}$ (fig. 2). The whole area is characterised by

\footnotetext{
3 Graziadei 2004: 79-80, 92-95.

4 Lavecchia-Macaione 2007: 87-124; Insetti 2013. The project, at the date of preparation of this paper, has not been launched yet.

5 Fascetti 2012.

6 The area was once known as "Vallone delli Lavandari", (Biscaglia: 2003/ a: 209).
} 
rather shallow aquifers, as evidenced by several outflows of groundwater and the presence of numerous shallow wells 7 . Particularly significant are the outflows of water from calcareous rocks, at several points in the lower part of the town, and especially at the base of the rocky body towards the valley floor.

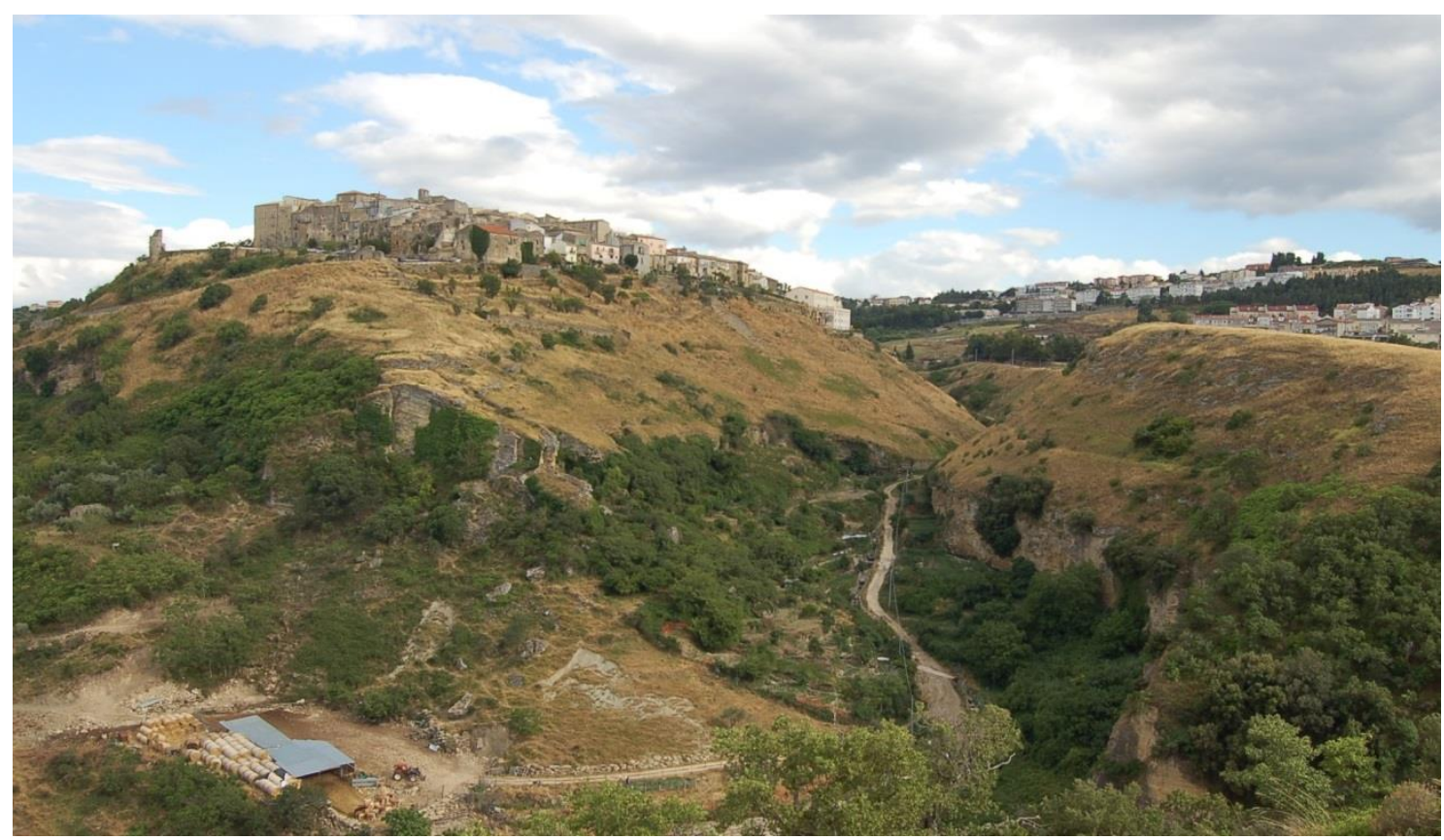

Fig. 2. The Cacarone Valley, north view. In the foreground the Orti Saraceni, on the left the Saracena quarter.

In this area, between the buildings of Tricarico and the bottom of the valley, three agricultural areas develop, each with specific characteristics and organisation. The cultivated areas immediately behind the town are bound to dryland farming, while downstream two zones of irrigated crops, object of this study, are located (fig. 3). Various parts of the site are currently in a very serious state of neglect, due to the abandonment that the production areas have suffered in recent decades and some rather invasive interventions that have altered the original pattern.

An end of the sixteenth century code $^{9}$ gives evidence of numerous vegetable gardens and orchards located immediately behind the town and in the area of the Conca of Sant'Antonio ${ }^{10}$. Many of these agricultural areas constituted, and still do today, an extension to the outside of the housing and some palaces located in the outer part of the settlement. The close relationship between the buildings and the nearby cultivated areas is also proved by an important iconographic source dating back to the beginning of the seventeenth century, which provides a valuable view of Tricarico and of some of the agricultural areas here analysed ${ }^{11}$ (fig. 4). The same sources also attest to the abundance of water in the area, as evidenced by the existence of fountains, aqueducts, wash-houses and

\footnotetext{
7 Lavecchia Macaione 2007: 92 n. 7.

8 Therefore they will not be covered by this study.

9 The edition of the text is contained in Biscaglia 2003/b.

10 Biscaglia 2003/b: 51-55, 60, 88, 222.

11 Braun Hogemberg 1618.
} 
devices for water management ${ }^{12}$. The code also documents the use of water from several fountains in the Conca of Sant'Antonio to irrigate vegetable gardens located in this area ${ }^{13}$.

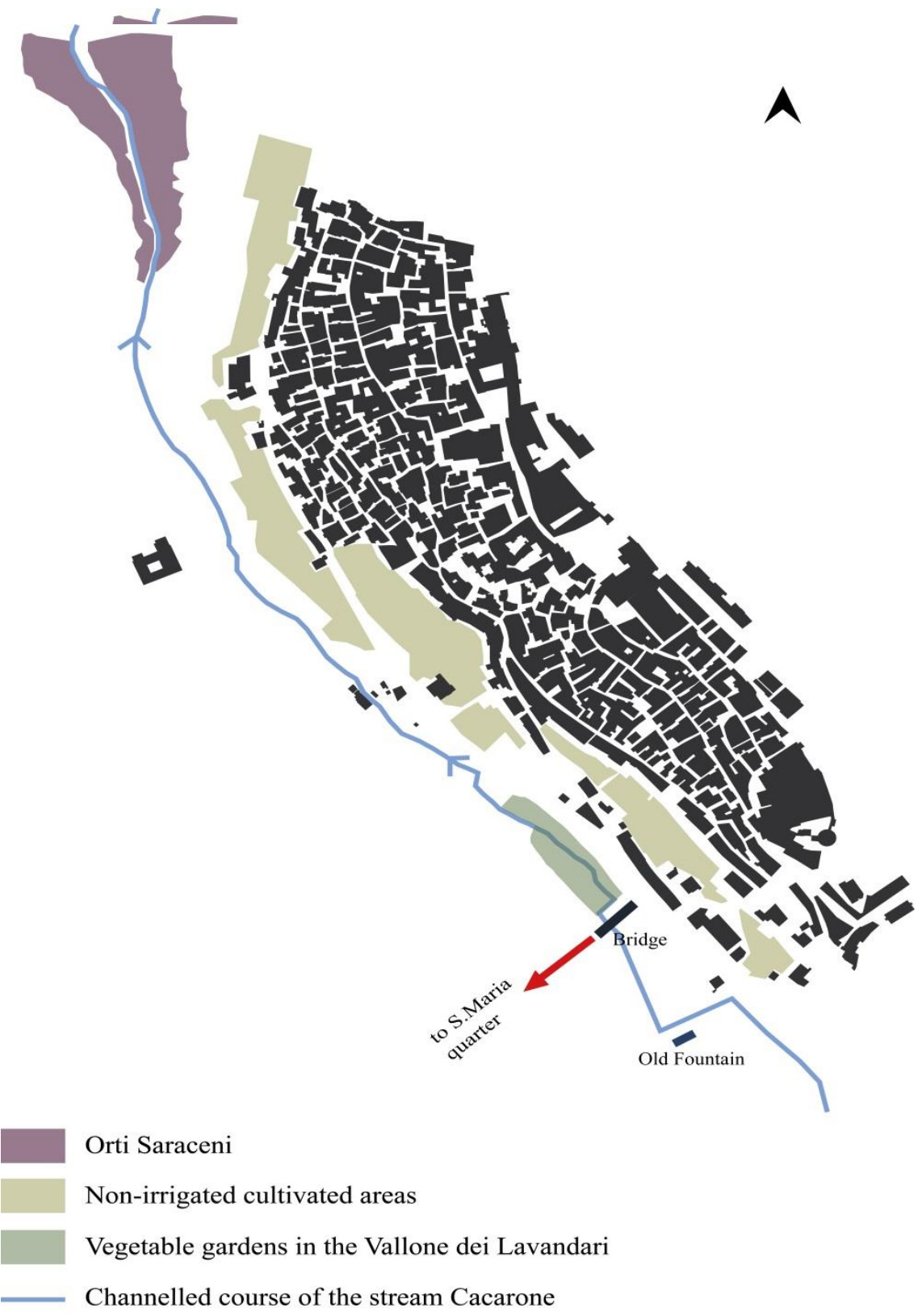

Fig. 3. The agricultural areas of Tricarico.

\footnotetext{
12 Biscaglia 2003/b: 67-8, 88-9, 163-4, 184, 195.

13 Biscaglia 2003/b: 67.
} 


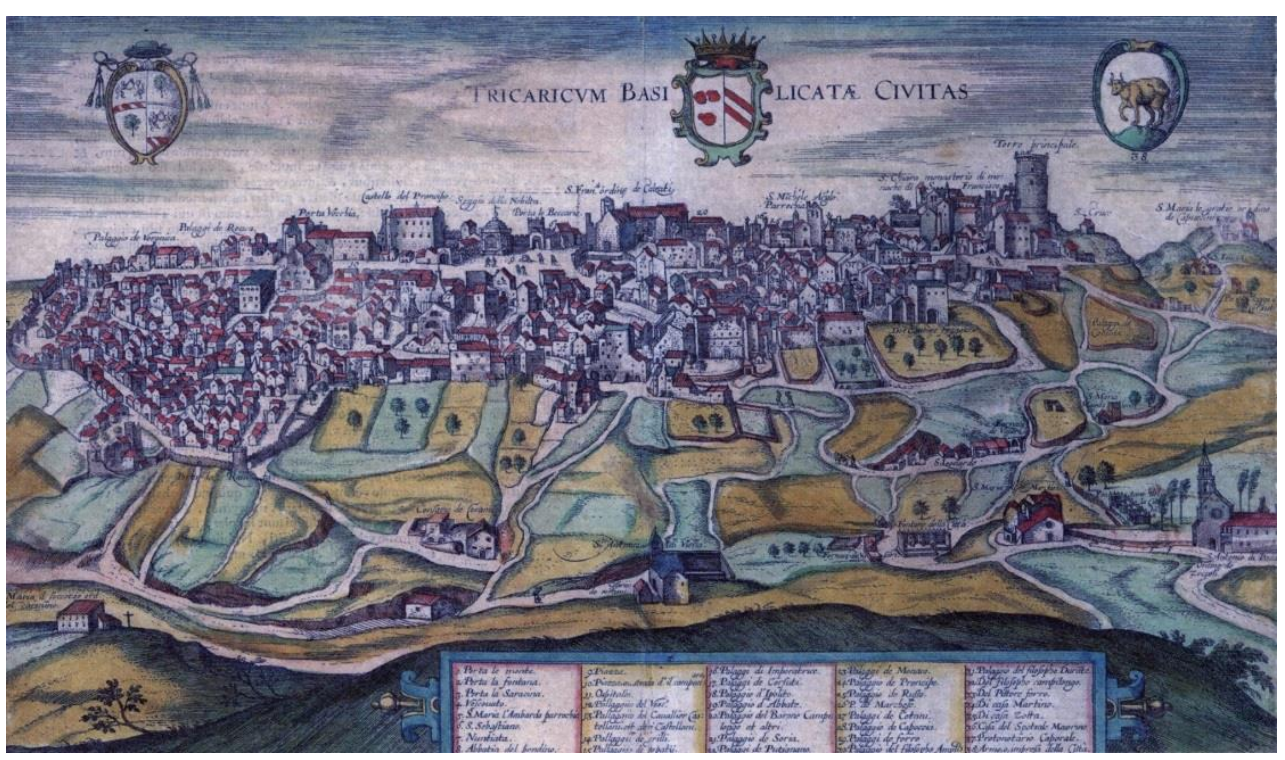

Fig. 4. The Braun-Hogemberg view.

\section{Vegetable gardens in the "Vallone dei Lavandari" (Valley of the Washers)}

The area between the historic centre and the modern Santa Maria quarter is called the "Vallone dei Lavandari", at the bottom of which the stream Cacarone flows. The cultivated areas here are essentially horticultural and use the waters of the springs that surround the basin, most of which flow into the stream. The latter, for a large part of its track, was channelled into concrete embankments in the part most upstream, and then into the sewer conduit that has partially exploited the riverbed. The stream, despite the changes it has undergone, before flowing into the sewer, continues to be the main water source for most of the gardens located in the upper part of the valley.

A stone bridge divides this cultivated area into two parts: upstream, up to the wash-house and the Old Fountain, and downstream, down to the mouth of Via Badia. The first part has undergone various interventions which have progressively altered it, up to having completely erased its agricultural nature. The part downstream of the bridge, instead, consists of a strip of land, long and narrow, bounded to the east and to the west by retaining dry stone walls.

The stream water currently flows in the stretch between the fountain and the bridge, in an artificial underground bed, on top of the sewer before returning, for a few metres, to flow in the open. The short stretch where the water flows to the surface is located at the arch of the stone bridge that crosses the stream and leads to the monastery of St. Anthony. Under the bridge, a diversion system consisting of small dams, channels and sluices allows diverting the water (fig. 5) and directing it towards two artificial channels that run on both sides of the river bed, close to the retaining walls in dry stone that define the cultivated area. Immediately downstream of these devices a check dam carries the non-diverted water to a lower level and channels it within the sewer in the lower part of the riverbed, where the stream flowed before. The height difference between the area upstream and downstream of the bridge, whether deriving from natural phenomena of sedimentation or being artificially produced to keep the water at a higher level than that of the cultivated areas, is functional to its distribution by means of gravity alone. 
The structure of this part of Tricarico's gardens can be summarised with the stream ${ }^{14}$ in the central area and the two main irrigation channels at the outer edge of the irrigated area, upstream. Between the channels and the river, on both sides, the cultivated fields develop, arranged with a slight slope in both the sliding direction of the stream and the one perpendicular to it (fig. 6).

The gardens are made up of plots of mainly rectangular or trapezoidal shape and, in general, with the short side parallel to the stream. Those located on the right bank spread all from the irrigation channel to, roughly, the watercourse, first without intermediate subdivisions and then on two terraced levels. Those on the left bank are almost all spread on a single level.

In the perpendicular direction to the river, the border between a plot and the next one is represented by narrow rammed-earth walkways flanked by secondary irrigation channels. The plots are supported by dry stone walls which, as well as defining the channelled waterway, also drain the water surplus of the land on either side of it. Therefore, a small valley-floor irrigated area is shaped, with cultivated areas on both sides and without transverse terracing, in which both the catchment of water for irrigation and drainage of the excess take place in the river ${ }^{15}$.

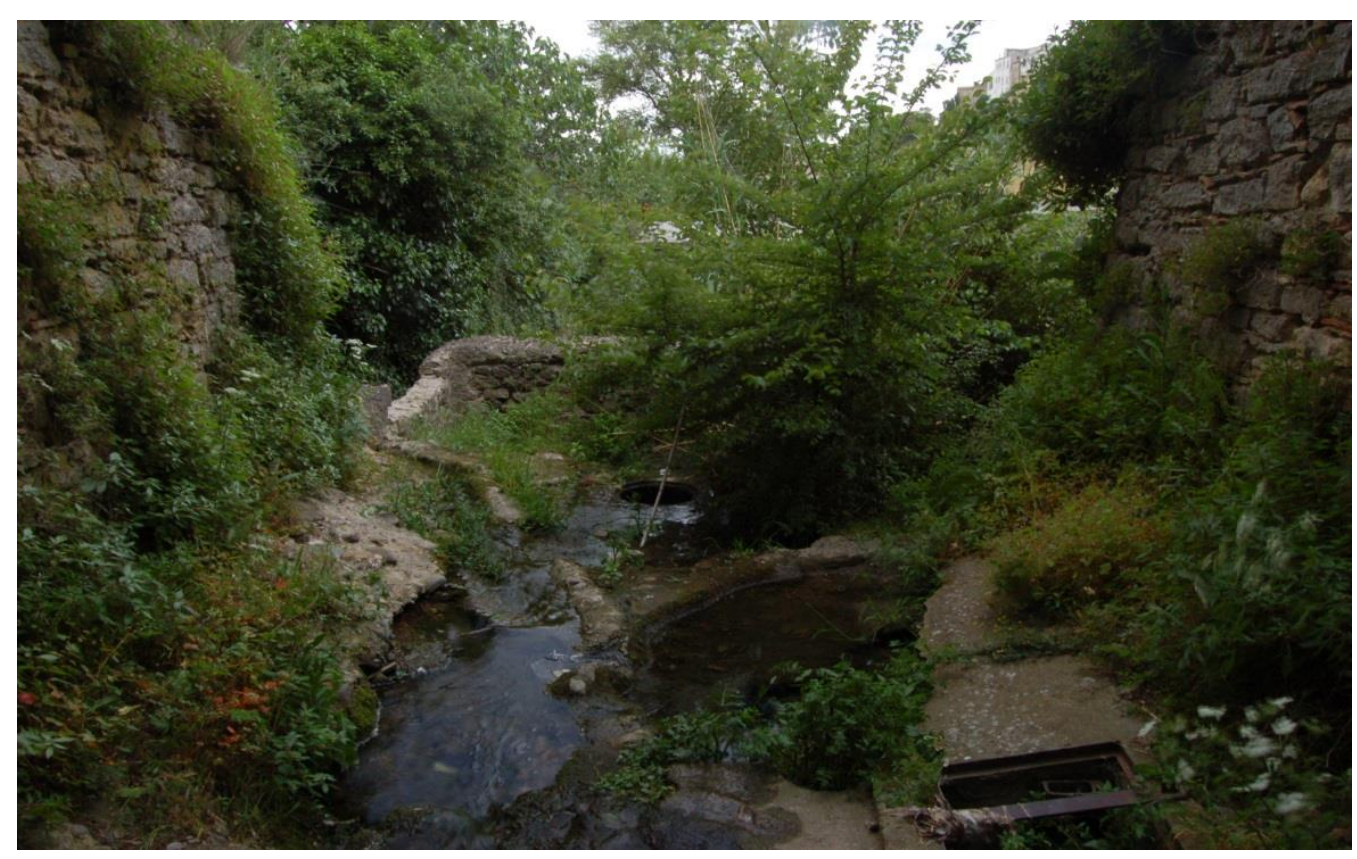

Fig. 5. The diversion system upstream of the vegetable gardens of the Vallone dei Lavandari.

\footnotetext{
14 This expression is preferred in this paper even if it has been transformed into sewer.

15 Ron 1966b: 116; Glick-Kirchner 2000: 279-280; Kirchner 2010: 134.
} 


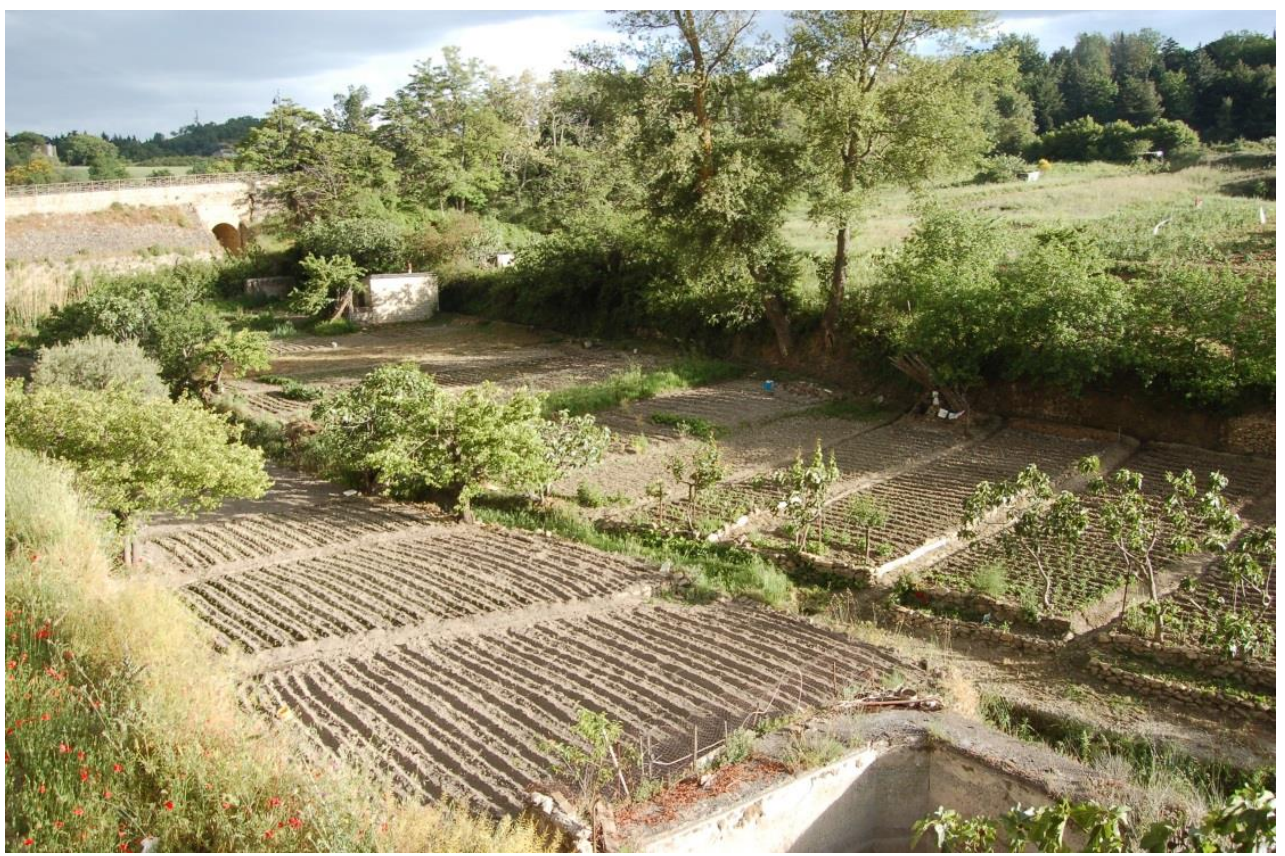

Fig. 6. The vegetable gardens of the Vallone dei Lavandari, north view.

The two main irrigation branches flow in earthen channels ${ }^{16}$ with U-shaped section, except for the right one that shows short stone sections. On both channels, the banks are reinforced with waste materials of various kinds: metal sheets, blocks or slabs of stone, wooden planks (fig. 7).
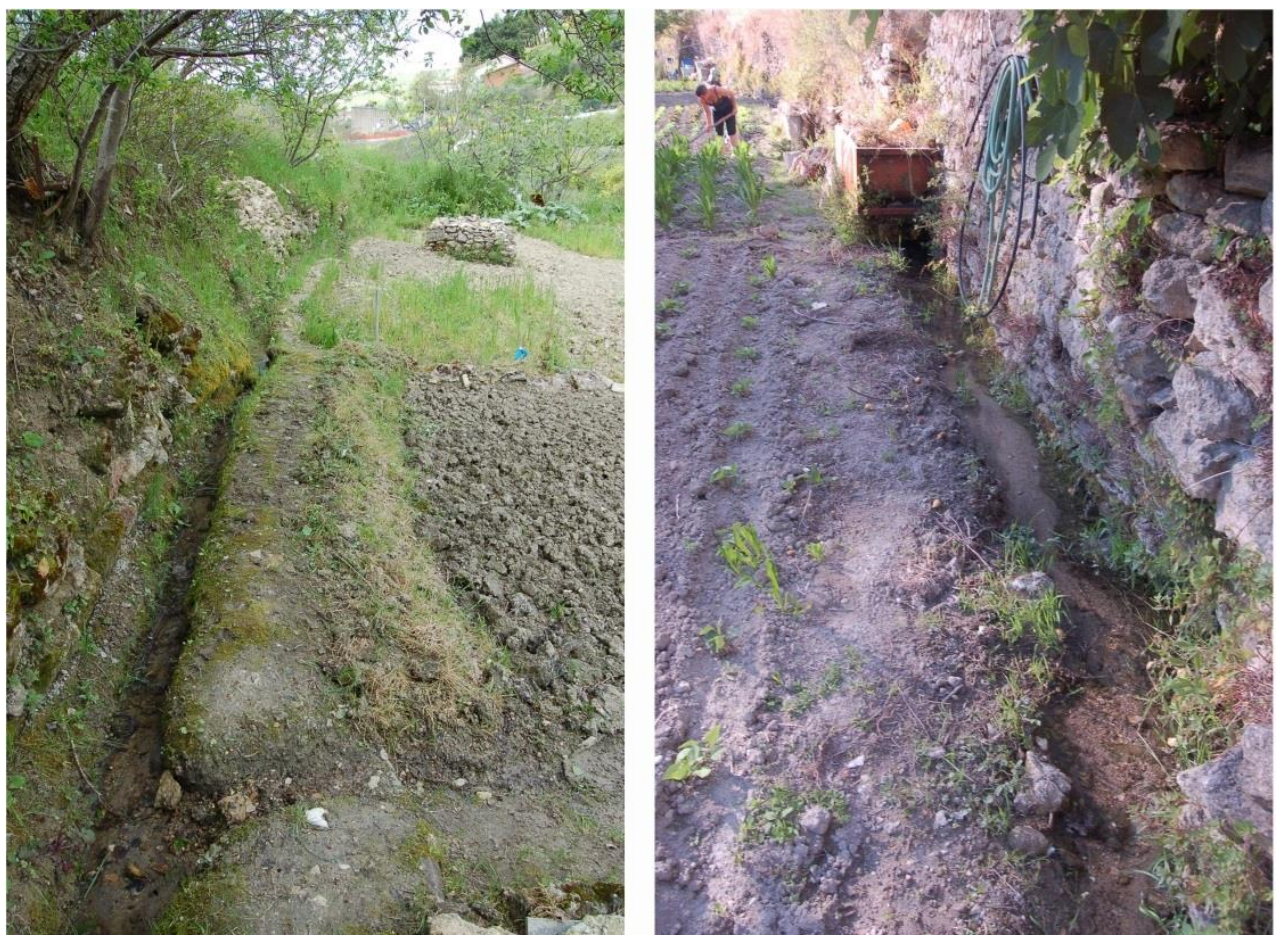

Fig. 7. The two main irrigation channels in the vegetable gardens of Vallone dei Lavandari.

16 The average size of these sections is approximately $0.25 \times 0.20 \mathrm{~m}$. 
The secondary ones are also earthen channels ${ }^{17}$ and divert water from the main channel towards the long side of the plot that needs irrigating, following the slope down to the riverbed. At several points, both to the right and the left of the cultivated areas, the secondary channels pass under the rammed-earth walkway through a short underground canalisation. Otherwise, they intersect it on the surface, and this happens mainly in the left portion of the stream.

Along the right channel, there are some devices whose function is related to the water flow management: two cisterns and some underground drains. The two cisterns are both uncovered and have very different characteristics and shape. The first one is semicircular and of a rather limited size ${ }^{18}$, leaning against the bottom of the retaining wall and bounded by a low wall of stone blocks shaped in a semicircle (fig. 8). Its supply comes directly from the main channel, simply diverting its course with a stone or a small tinplate. When not supplying it, the channel follows a semi-circular path on its outer profile, bordered by rather irregular stone blocks. The cistern has an outlet on the bottom connected to the stream by an underground pipeline. Currently, the device is used for washing vegetables. Outside of the cistern, in the stretch of the semicircular channel that frames it, a drop (i.e. a sewer trap) opens leading the water to the same underground drain that discharges into the stream.

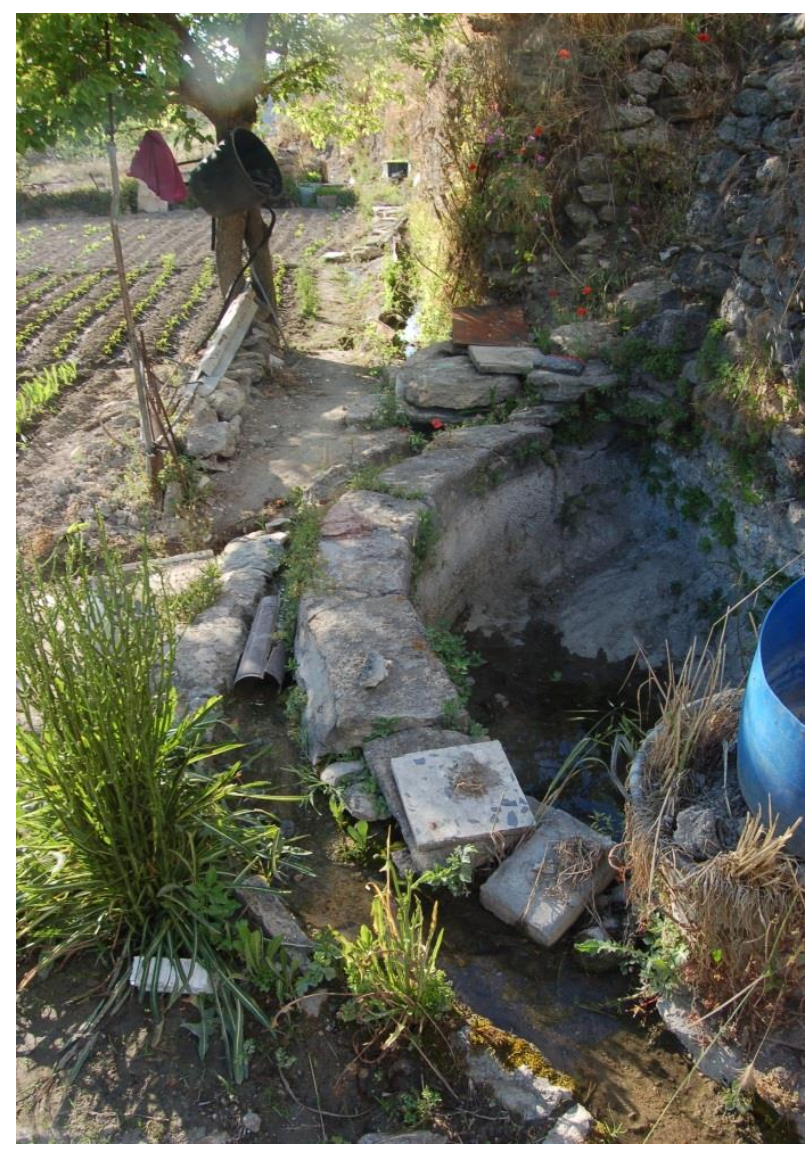

Fig. 8. The semicircular cistern in the vegetable gardens of the Vallone dei Lavandari.

\footnotetext{
17 In this case, the average size of the sections is approximately $0.20 \times 0.10 \mathrm{~m}$.

18 The diameter is about $2.40 \mathrm{~m}$ with a depth of about $0.70 \mathrm{~m}$.
} 
A few meters downstream of this semicircular cistern, the main channel supplies the second cistern. The latter is much larger than the former, and has a quadrangular plan ${ }^{19}$ (fig. 9). The stonework is uneven and plastered only on the inner surface. The water is accessed through a bypass channel made of stones and concrete that passes through the thickness of the wall in the east corner of the cistern. In the opposite corner there is an overflow, while the water outlets in the lower parts of the cistern were not located, and neither was, given the neglect state of the terrace below, any water distribution system originating from the cistern.

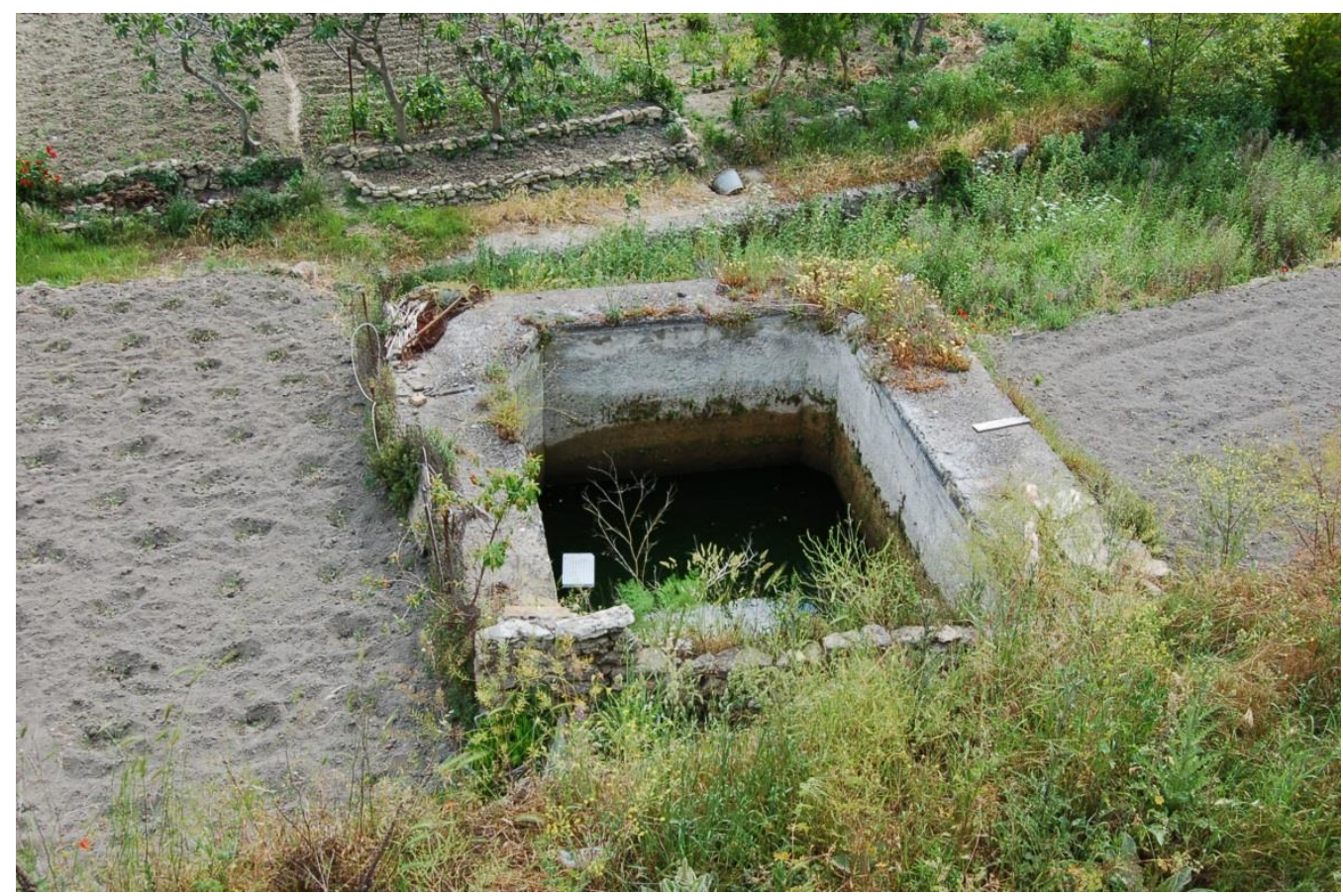

Fig. 9. The quadrangular cistern in the vegetable gardens of the Vallone dei Lavandari.

Clearly, given the size, they are two different types of water accumulation. The modest capacity of the first cistern may involve a small quantities of water collection, for very limited uses and, as seen, other than irrigation. The second cistern, instead, appears to act more as a reservoir for periods of drought. The cultivated plots, on the right bank of the river downstream of the cistern, change their configuration. They go from one level to two consecutive levels, in the direction perpendicular to the stream, both supported by dry stone walls.

Downstream of the second cistern, the main irrigation channel has a branch that leads the water to the terrace below. The right main channel keeps flowing on the highest level of terraces up to joining, a few metres further downstream, the channelled stream, as well as the left one. The cultivated areas are organised within the plots according to furrows usually parallel to the course of the stream, within which the plants are lined up on the margin downstream. Rarely the furrows are perpendicular to the stream. In the first case, the supply comes from the secondary channels, while in the second one it comes directly from the main channel (fig. 10).

19 The internal measurements are: $3.80 \times 5.45 \mathrm{~m}$, at a depth of approximately $3.00 \mathrm{~m}$. 


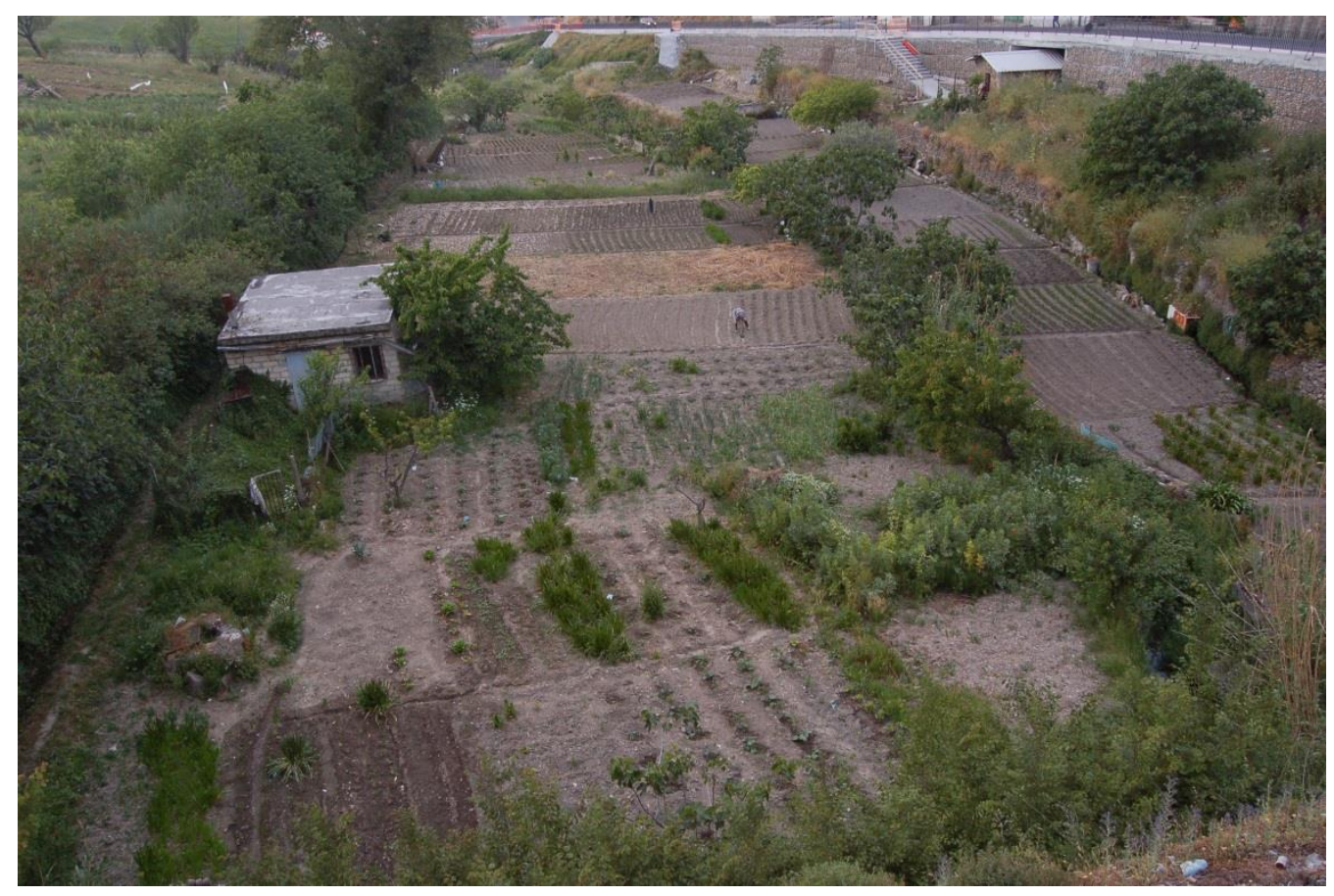

Fig. 10. Primary and secondary channels in vegetable gardens of Vallone dei Lavandari.

This area of gardens in Tricarico is also characterised by the presence of several wells. They are usually quite superficial and their inner walls are made of irregular stone. Their position within the plots is in the part most upstream, so that the supply of the irrigation channels is smooth and the circulation of water can always occur by gravity. The wells are all located on the left side of the stream, not only in the gardens closest to it, but even in the ones most upstream, in the direction of the Santa Maria quarter. For plots that also make use of the river water, the wells represent an alternative or supplementary source when the water flow is low. In other cases, they are only an alternative source to rainwater.

\section{The "Orti Saraceni" ${ }^{20}$ (Saracen Gardens) area}

Another agricultural area is located near the confluence of the Cacarone in the Milo, in that part of the valley which is in correspondence to the Saracena quarter. Here, first the valley narrows and begins to deepen considerably, while then it widens again in the final part.

Unlike the plots most upstream, the ones of this area do not use the river waters and have a different spatial organisation. The gardens in this area use mainly the water drained from the overlying bedrock and they are arranged in terraces.

The Orti Saraceni are then related to the type of terraced hillside systems, where the water source is located on the same side on which the agricultural area develops ${ }^{21}$ (figs. 11, 12). The irrigated terraces of this type represent the most complex and advanced stage among the terracing systems, and their implementation and management requires a great mastery of construction, hydraulics and agricultural knowledge, as well as a thorough understanding of the characteristics of the site.

20 This place name was introduced by Pietro Laureano (Laureano 1988: 109) and is now commonly used. The area is also called "orti del Milo" (gardens of the Milo).

21 Glick-Kirchner 2000: 283-4. 


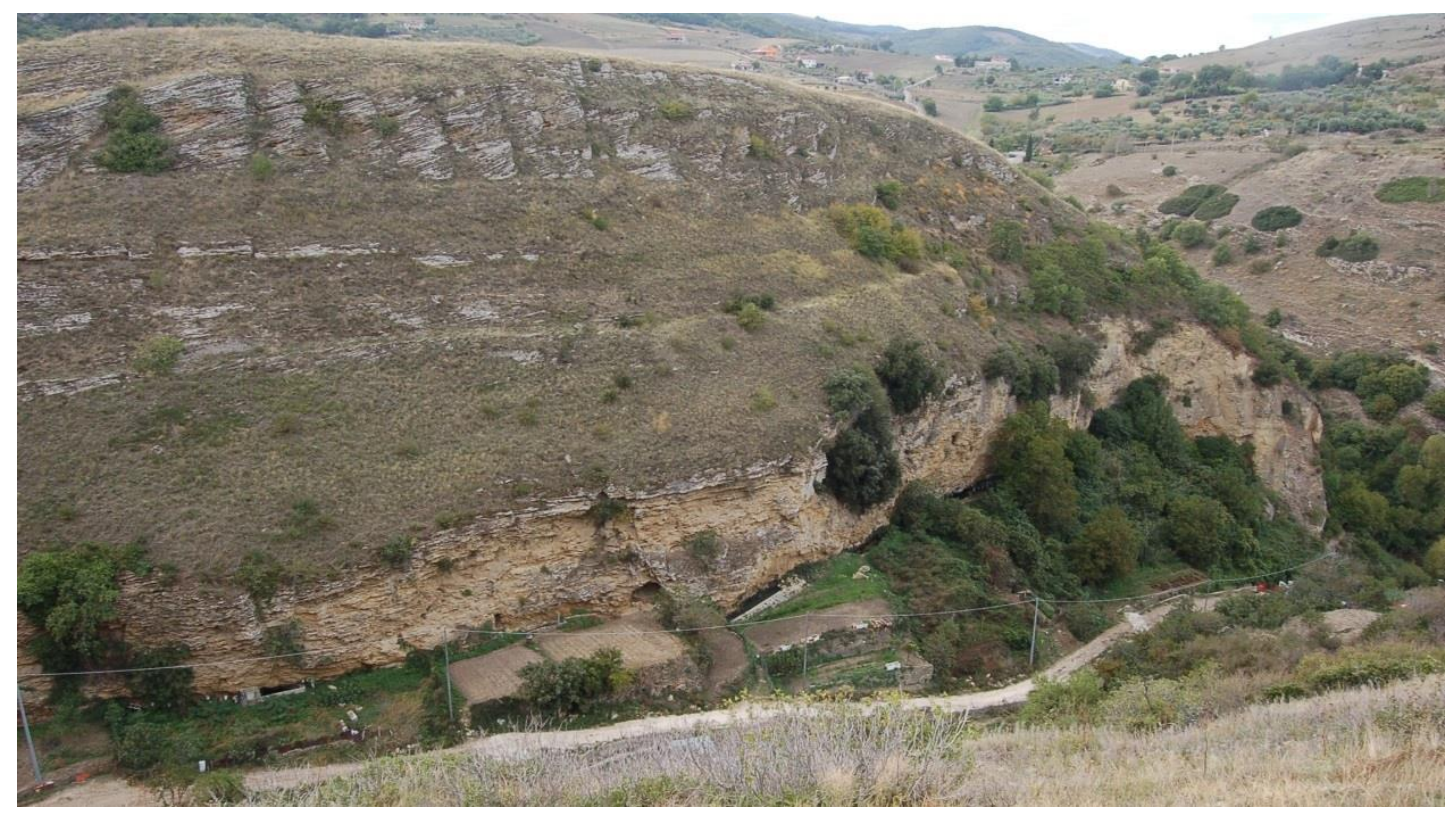

Fig. 11. The Orti Saraceni seen from the Saracena quarter. Some of the cisterns are visible at the base of the rock.

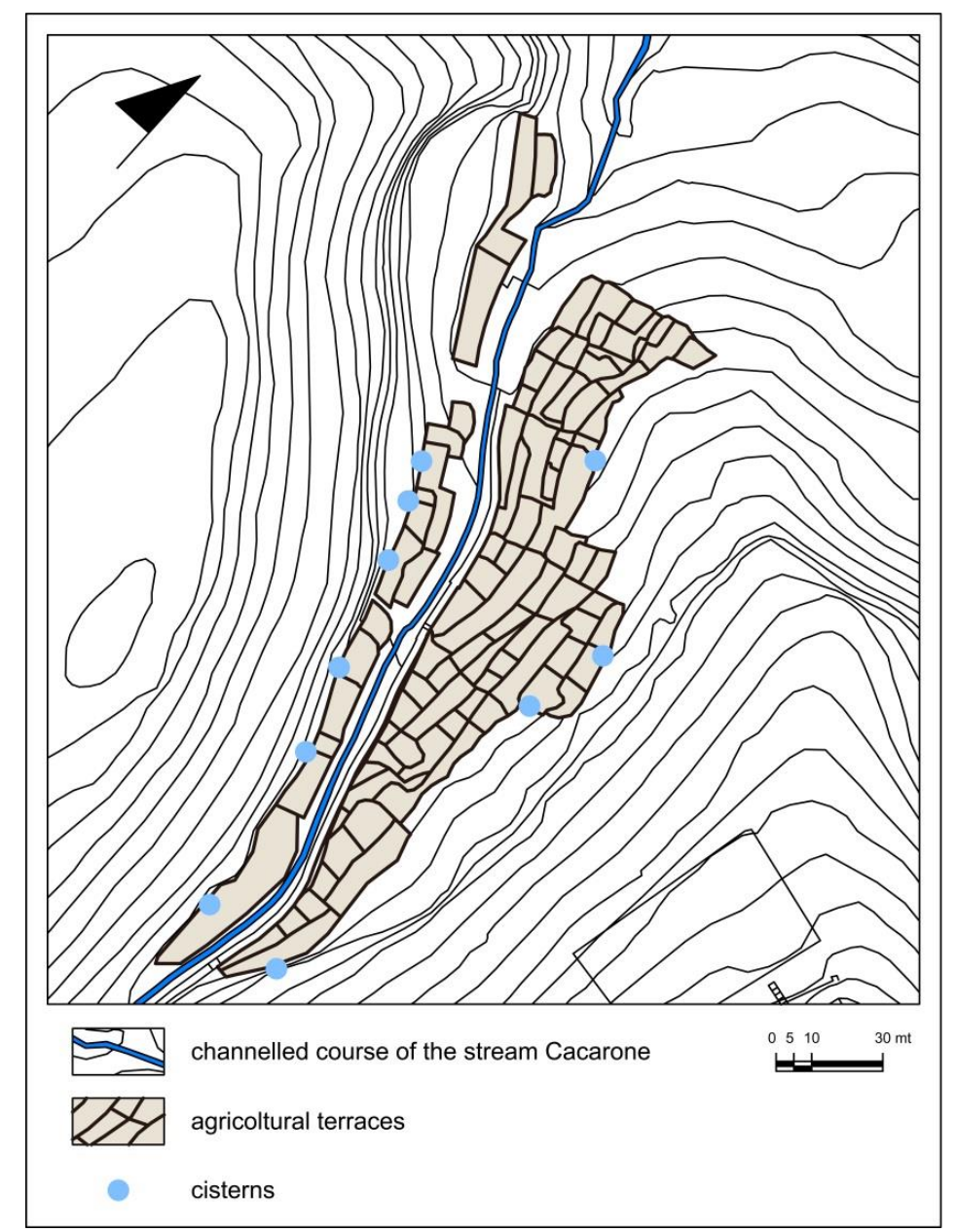

Fig. 12. Schematic plan of the Orti Saraceni. 
Although the area is rather small22, changes made to the original site to turn it into productive space, as it appears today, have been impressive. However, even in this case, the area has in part been altered by the construction of the sewer and the cementing of the bed of the stream, the creation of a sewage treatment plant near the terraced area and the opening of a service road. In addition to these changes, the site has particularly degraded areas due to the abandonment of many agricultural plots ${ }^{23}$. The two calcarenitic reliefs of the town and the opposite hill show sides that go from being very steep to being subvertical or vertical where the agricultural land develops. The area between the base of these cliffs and the stream is entirely occupied by the terraces of the Orti Saraceni. The walls that support the agricultural plots are all made of dry stone and have rather variable heights, but typically between about 2 and $4 \mathrm{~m}$. They are based directly on the rocky soil, although it is not clear whether this was previously modelled by steps or if the installation was done on the natural profile.

Unlike the plots in the area of Lavandari, the Orti Saraceni are constituted by almost perfectly horizontal plots, in which the retaining wall is generally a little higher than the ground supported by it, even if the irrigation does not occur by flood. The terraces have widths ranging from 4 to $7 \mathrm{~m}$, but there are larger plots, especially on the left side of the valley and in the first part of the right side. The shape of the plots comes from the adaptation of the retaining walls to the contour lines. A rather sinuous trend follows, most evident in the longer terraces. The latter are subdivided in smaller portions by transverse walls a few tens of centimetres high, in order to maintain the horizontality of the cultivated area and spread the gradients that would otherwise be substantial.

The alignments of the walls in the direction perpendicular to the course of the stream usually mark the boundaries between the properties and usually coincide with height differences between two consecutive terraces. The connection between terraces placed at different heights can be made through inclined planes, single or divided into ramps, and supported by dry stone walls, or via stairs or steps between two successive retaining walls. The paths within a plot develop near the retaining walls (fig. 13).

22 Approximately 1.5 ha.

23 The conservation status of the sites and the dense vegetation often make it difficult to correctly survey and understand the structures. 


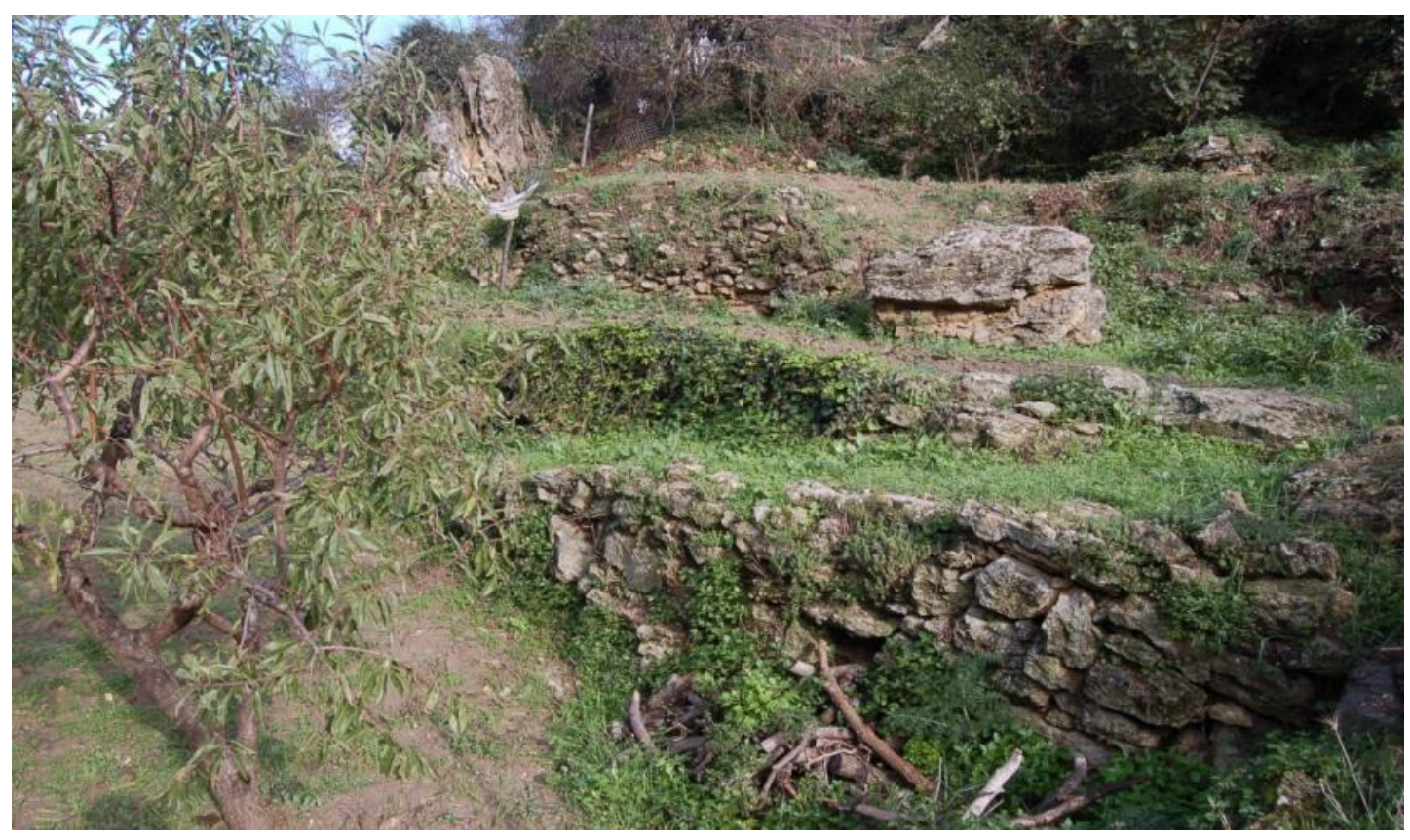

Fig. 13. Connection between terraces at different heights in the Orti Saraceni.

The water used for the irrigation of the Orti Saraceni comes from calcareous formations on which the cultivated plots develop. At several points on both sides of the valley the aquifer is exposed and the water emerges from the rock, creating weak but steady flows throughout the year.

Flows of this kind, even if persistent, do not guarantee the water circulation and, if not managed in a timely manner, will be lost in the ground near the outflow. Farmers who created the terraces in the Cacarone Valley made the most of the site features, and created a series of devices that allow turning the water outflowing from the rock into a source capable of supplying the terraced areas of the Orti Saraceni.

In places where the water outflows, some cisterns were built at the base of the cliff to collect any small amount of liquid that came out and to keep it. The cisterns, locally called peschiere (fishponds), are generally of elongated shape and are positioned at recesses in the sub-vertical profile of the calcarenitic bank (fig. 14). Through these structures the water flow can be stored up to reaching such quantities as to allow, at a later time, a circulation within the plots and a regular irrigation. 

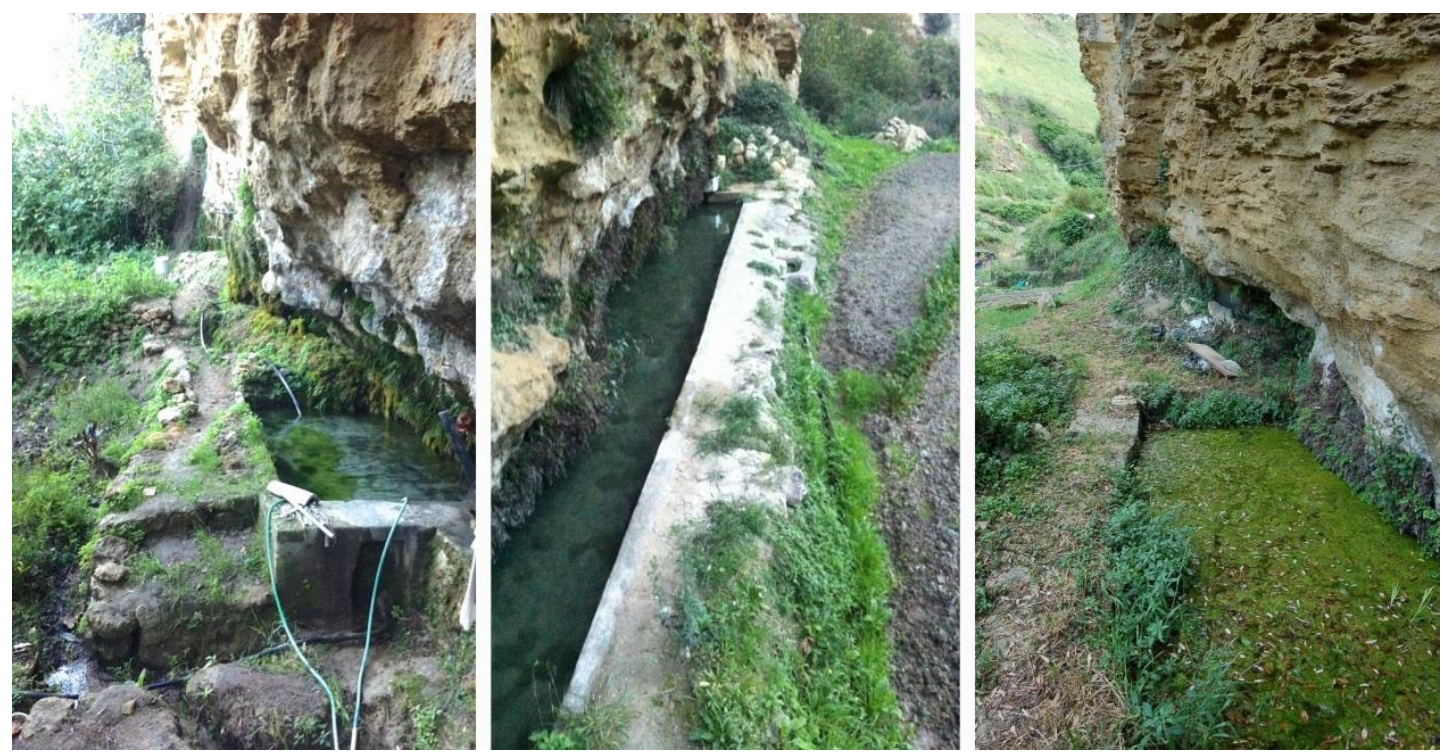

Fig. 14. Cisterns in the Orti Saraceni.

The natural recess is often regularised and, at times, horizontally deepened ${ }^{24}$ so that the cistern is partly hidden by the rock (fig. 15). With this solution, the drained surface - and so the amount of collected water - is greater than in the case of the cistern simply flanking the rocky wall, as not only that which flows from the floor and from the vertical walls is captured, but also that dripping from the ceiling.

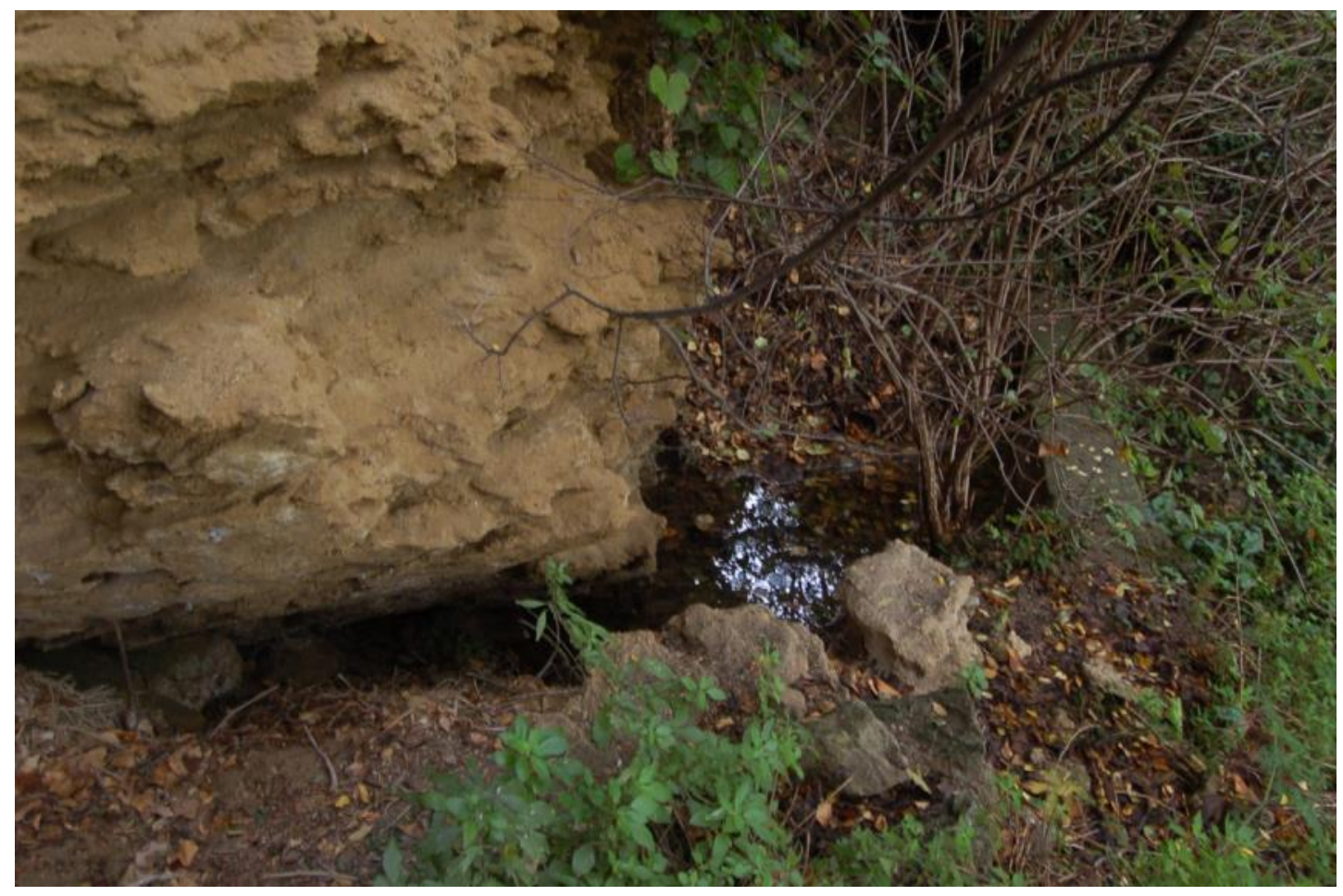

Fig. 15. A cistern partially hidden by the rock in the Orti Saraceni.

24 These portions below the rock are usually not very deep and rarely more than a metre. 
Sometimes, near some cisterns, caves are excavated, which penetrate a few metres into the rocky body (fig. 16). These artificial caves have the function to intercept the saturated levels and so increase the amount of drained water in order to cope with a lowering of the aquifer or with an increase in water demand. They are usually placed at a higher level than the cisterns, to which they connect through ducts carved into the rock or soil. In many cases, a network of channels, also cut into the rock or delimited by stones, transfers the overflow of a cistern to the other at a lower level, and allows supplying all the cultivated plots, even those where there are no outflows or these are insufficient.

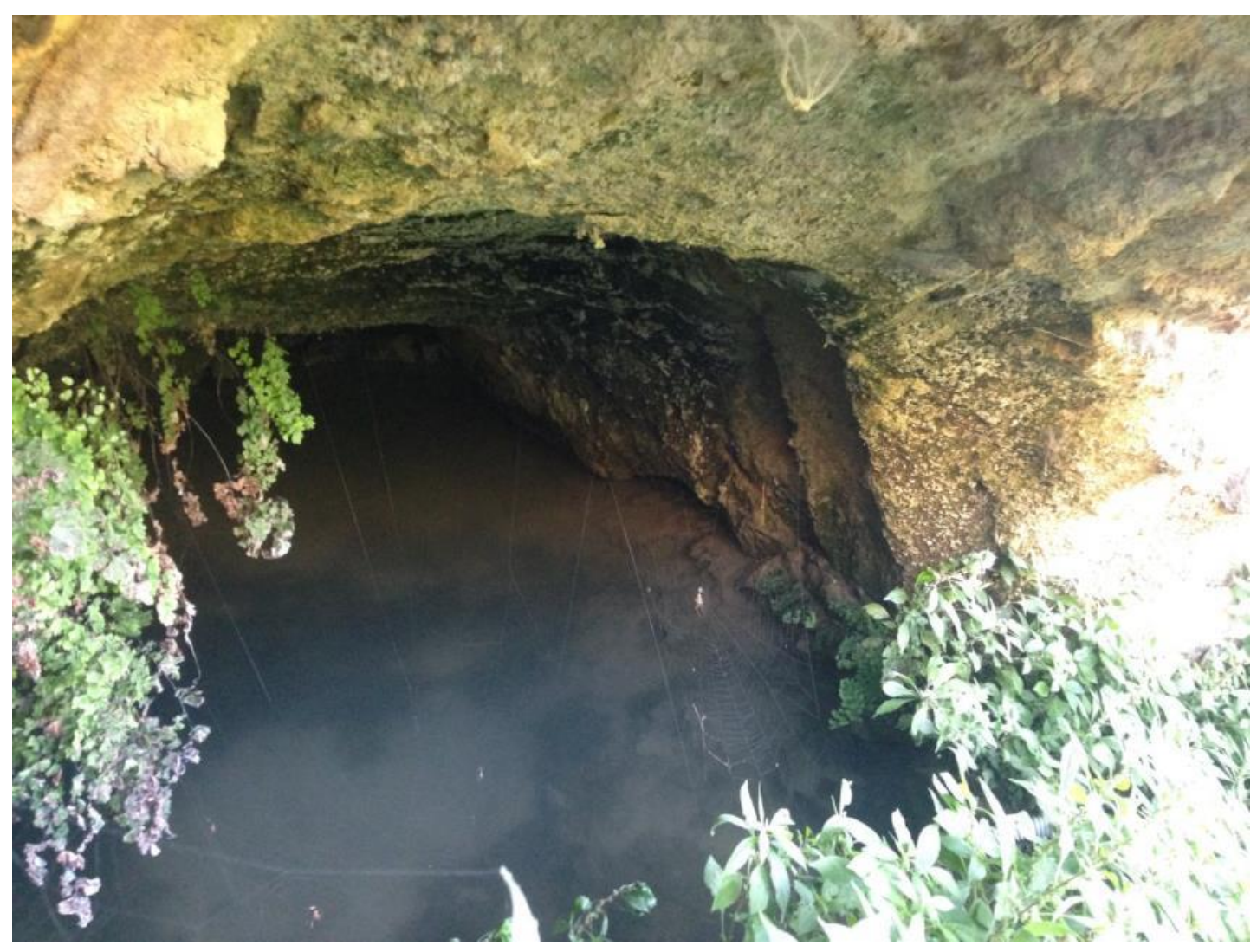

Fig. 16. A cave excavated in the Orti Saraceni.

The cisterns are made of masonry and waterproofed by a plaster coverage where there are no outflows. The size is very variable, being influenced by the morphology of the rocky wall and the exposure extent of the aquifer ${ }^{25}$. Where the rocky body is more fragile and crumbles easily, between this and the cistern a dry wall is interposed, probably in order to both prevent instability and consolidate the rock body, and to better drain the water from the loose rock portions (fig. 17).

From the cistern an open channel originates, made of stone or tiles, or, at other times, dug directly into the ground. Usually this channel, in the plot at the same height of the cistern, directly supplies the crops grooves, which tend to be parallel to the valley. When the cistern also serves lower terraces, the water flowing from the main channel faces various heights achieved through drops inside the wall or through spouts, gutters and small slides on the outside of the walls. In the lower terraces, the main channel is generally in a

25 The width is usually between 1.20 and $2.50 \mathrm{~m}$, of which only a part projecting from the bedrock. The length is very variable and can even reach up to $12 \mathrm{~m}$. 
peripheral position, usually along one of the short walls. The grooves of the crops are mainly directed to the primary channel, thus being parallel to the length of the terrace. There are rarely secondary channels and, in a few cases, crops are arranged in grooves perpendicular to the valley. At several points, especially on the lowest terraces, the water drained by the dry stone walls of the upper terraces is collected in small puddles molded directly into the ground. In some cases, they may also be supplied by small underground ducts directly from the cisterns below the bedrock.

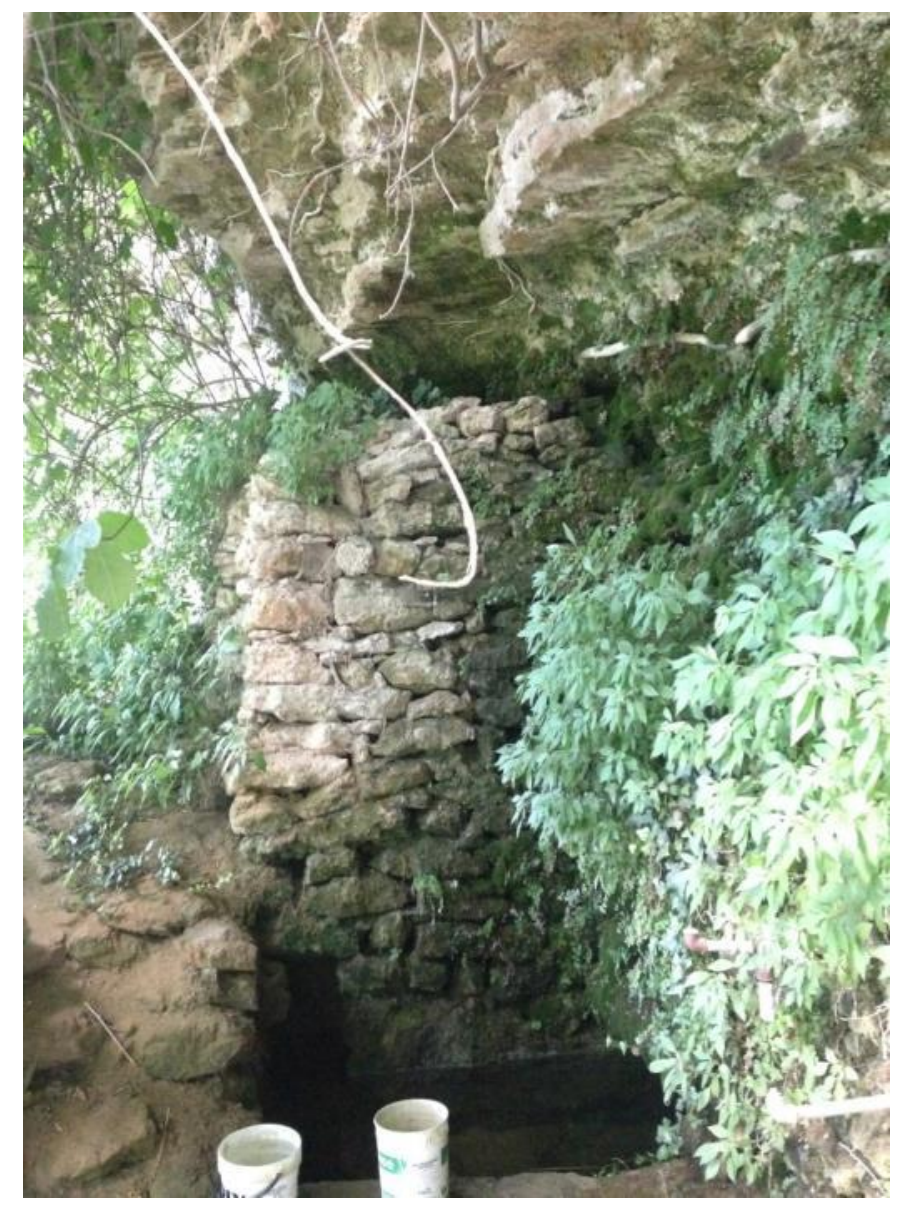

Fig. 17. A dry stone wall interposed between the rocky body and a cistern in the Orti Saraceni.

\section{Waters, lands and town. Knowledge and practices for the management of agricultural areas}

The water that supplies the irrigation areas of Tricarico's gardens, given also the limited extension of the crops and the absence of different uses, is currently far beyond the agricultural needs. In view of this abundance, the division of the various plots is not subject to scheduling arrangements, but simply to verbal agreements among the farmers ${ }^{26}$. This way, when the gardens of Lavandari need irrigating, the stream flow is diverted towards the right or left channel as needed. After the irrigation procedures, the sluice is

26 Evidence about the past regulation of water distribution was not identified at the time of writing this paper. 
closed and the water flows back into the stream. Regarding the Orti Saraceni, the water of the cisterns whose flow is greater, is distributed to those where the flow is lower or, in some cases, is directed towards cisterns in the plots that do not have direct access to the sources. In similar situations, the overflow is channelled directly to the other cisterns, still under verbal agreements.

Water management is only one element in a series of practices, knowledge and skills related to the common intangible heritage that, generation after generation, have developed and continue to keep the gardens of Tricarico alive. Both in the gardens of the Vallone dei Lavandari and in the Orti Saraceni, water is distributed to the areas in need of irrigation in a similar way regardless of where it originates. Once the water has reached the plot, a small earthen embankment is modelled with a hoe in the bed of the channel. This way, the water is diverted towards the groove in need of irrigation, which is flooded starting from the most distant part from the diversion. After the groove is filled, the embankment of the channel is removed with a hoe and water is addressed, with the same procedures, to another groove, while the former is closed with another earthen embankment, to prevent water from leaking. Irrigation usually proceeds from the lowest towards the highest groove in the plot (figs. 18).

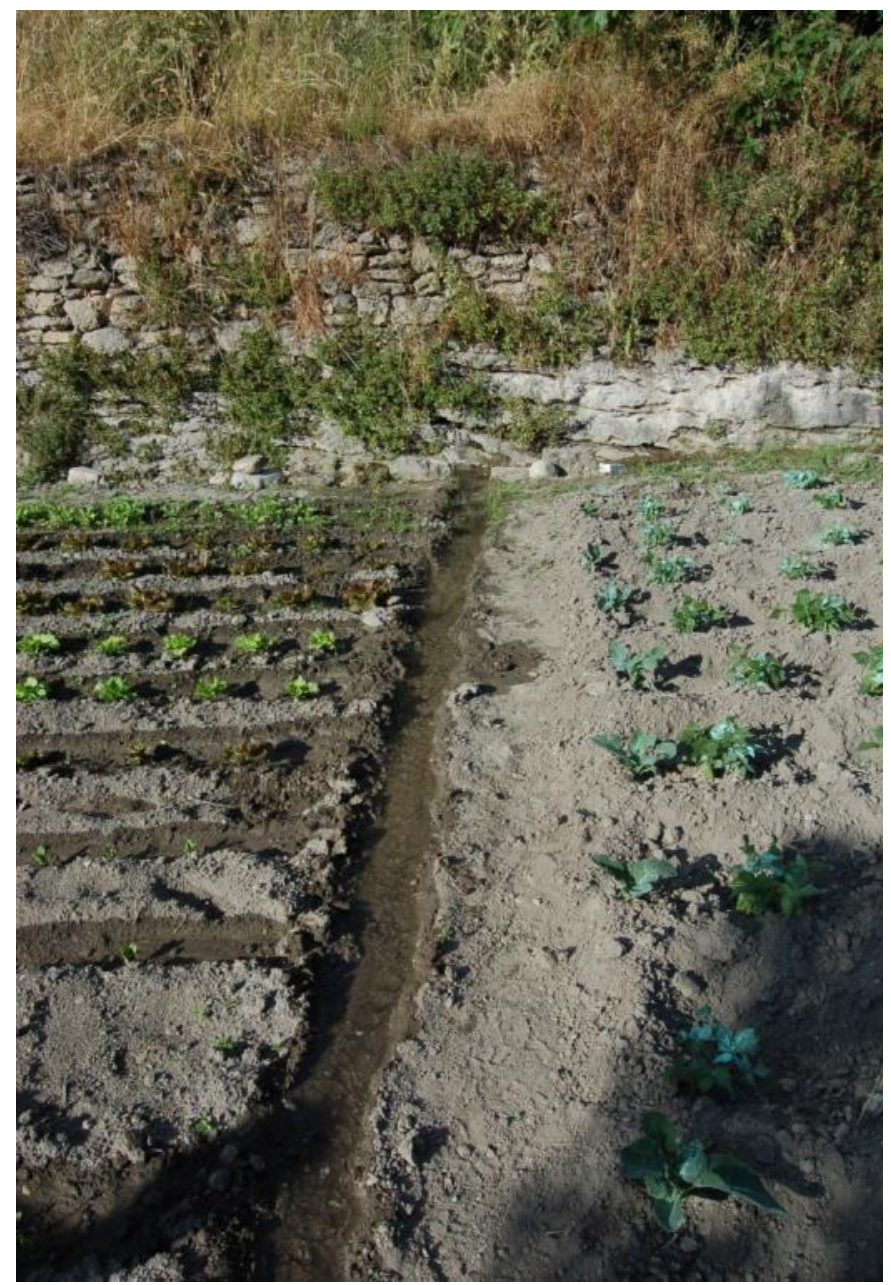

Fig. 18. Irrigation of the plots in the gardens of the Vallone dei Lavandari. 
The slope and the depth of the furrow to be irrigated are such as to avoid an excessive water speed, which would involve erosion or overflow phenomena from the banks. The water enclosed in the groove that has just flooded is slowly absorbed by the roots and this contributes, together with the foliage of plants that slows the evaporation, to maintain an optimal level of moisture in the upper layers of the soil.

Of course, to allow an efficient circulation of water inside both the grooves and the channels, they must retain the suitable slope and must be periodically cleaned from the dropped or deposited material. In addition to taking care of the distribution system within his own plot, each farmer takes care of the cleaning and ensures the continued operation of the portion of the distribution channel that runs through his property. Even the cisterns at the base of the bedrock should be periodically and completely emptied. This way they can be cleaned of debris from the disintegration of the rock surface that accumulates on the bottom, blocking the water outflow and reducing the capacity of the cisterns. With the manual processing of the land some mechanised procedures were usually combined, especially related to the preparation prior to planting. Of course, this happens only in areas accessible to small mechanical devices. Grooves opening, planting, as well as caring for the crops and the maintenance of channels, instead, take place entirely by hand, using small tools such as hoes, rakes and shovels.

Fertilising the gardens soil with animal manure before planting is common practice, as well as spreading the ash produced by the house chimneys at the base of cultivated plants. Practices of this kind are residual but clear signs of a link between urban and agricultural areas that goes beyond the physical proximity of spaces. The existence of exchange and interdependence dynamics between the two areas is made evident by the fact that the products of all the agricultural areas are intended for self-consumption by the growers themselves or for a local market only. The gardens are thus one of the food sources of Tricarico.

This relationship must have been even stronger in a not so distant past, when broader areas of the gardens were cultivated, or when the manure to fertilise the plots came from the numerous stables in the town ${ }^{27}$. In addition, before the implementation of sewage, both solid and liquid organic waste coming from the urban area contributed to the creation of humus and the fertility of the cultivated land.

\section{Comparisons}

The organisation and management systems of agricultural areas and the techniques for the exploitation of water resources of Tricarico are comparable with the production areas of very large geographic regions.

The soil protection, fertile soil creation and water production functions of dry stone walls have been exploited since ancient times, in more or less steep contexts and with scarce surface water resources, in the arid regions of southern Europe, northern Africa and the Arabian Peninsula ${ }^{28}$. The technique of diverting water from a perennial or seasonal watercourse, towards the two highest external sides, and from them towards cultivated

\footnotetext{
27 De Martino: 651.

28 Laureano 2001: 110; Harrower: 498.
} 
areas on the banks, refers to systems used in the South Arabian and East Mediterranean world since the third millennium B.C. ${ }^{29}$.

Valley floor or versant irrigated areas, based on equivalent devices and spatial patterns very similar to those described, are found throughout the Mediterranean basin and the Near East. Comparisons can be made from the Iberian Peninsula and the Balearic Islands ${ }^{30}$ to the Palestinian region ${ }^{31}$, from the Saharian wadi oasis ${ }^{32}$ to the mountains of Yemen ${ }^{33}$, from the terraces of the Amalfi Coast ${ }^{34}$ and Sicily to the valleys of Jordan ${ }^{35}$. In these contexts, organisations of agricultural spaces and water collection and distribution devices in terraced areas are found very similar to those of Tricarico. Strong similarities are also found in the practices of cultivation, irrigation and disposition of plantations within the plots $^{36}$.

With regard to collection systems and water management, cisterns and caves dug in the Orti Saraceni seem to refer to devices with similar functions and structures. The functions of collecting and storing flows which would not circulate within the plots in natural conditions, could be put in relation with those of a kind of cistern built for the same purpose in different irrigated areas in Yemen and Al-Andalus ${ }^{37}$. The function of this device, called ma'jizs in Yemeni Arabic, is to store water and make it available at a later time in such quantity and power as to cover the irrigation area, which is exactly what happens in Tricarico.

The practice of digging caves within a rocky body, in order to follow the aquifer and drain a greater amount of water, is rather common and of remote origin ${ }^{39}$. Examples of it are found, in the agricultural context, in the digging and progressive deepening of draining caves, until they turn into tunnels, in terraced areas in the mountains of Judea ${ }^{40}$. The small caves in the Orti Saraceni are dug for the same purpose of renewing or extending the flow.

\section{Tricarico's vegetable gardens and the Arab presence}

Most of the management systems of agricultural areas and water similar to those described above originate in the Near East, and have been refined and exported to the west thanks to Islam $^{41}$. In this connection, it may be interesting to relate the gardens of Tricarico to the presence of Arab and Berber populations in this and other towns of southern Italy between the ninth and eleventh centuries. The presence, during the ninth century, of

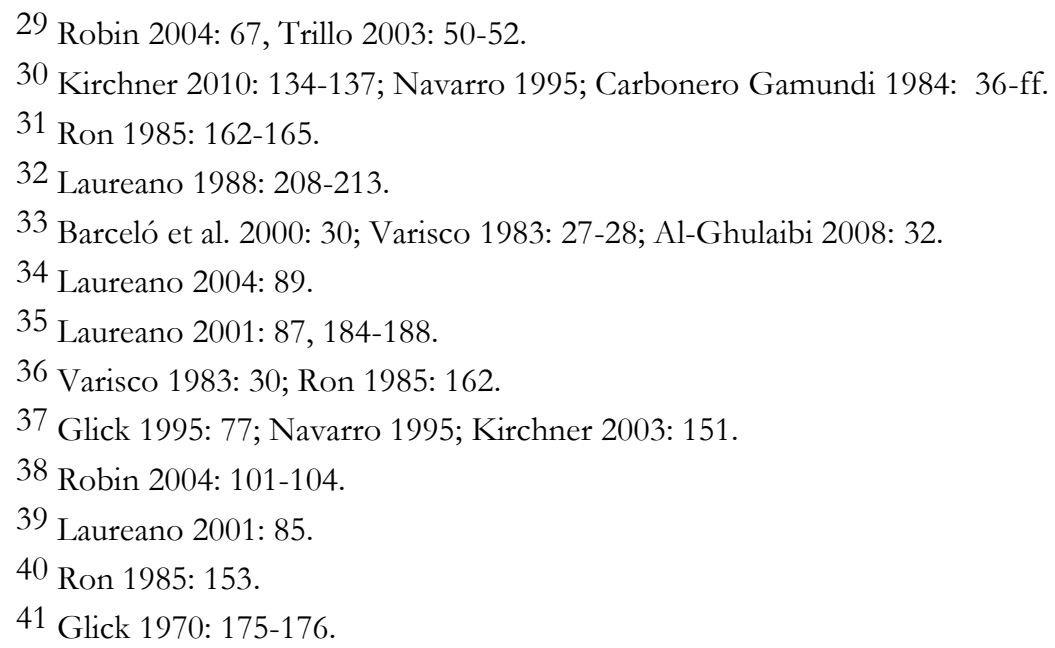


Muslim settlements in the Apulian cities of Taranto and Bari seems to have had particular importance for the inner regions ${ }^{42}$. It is likely that most of the "Saracens" who spent time in Basilicata between the ninth and eleventh centuries came from these two centres ${ }^{43}$. Although written sources provide proof of a mainly conflictual reality between local people and these populations, the legacy in place names, dialects and in structure of some cities seems to indicate the existence of even peaceful relations and integration ${ }^{44}$.

In some villages of Basilicata there are quarters whose names recall that of the Maghrebian ribāt $t^{45}$ : Tricarico features one Rabata quarter right beside the Saracena quarter. In the nearby areas, other examples are the Rabata of Pietrapertosa ${ }^{46}$ and the Rabatana of Tursi ${ }^{47}$. In these centres, as well as in several other southern Italian towns, to place names of Arabic origin are associated compact and labyrinthine urban fabrics with narrow streets, covered roads and bayonet alleys ${ }^{48}$.

Still in Tricarico the Saracena quarter, located upstream of the agricultural area, has, like its neighbouring Rabata, a strong hierarchy of routes and spaces, and a recurrence of residential places that can be isolated from the rest of the urban fabric, articulated around common uncovered areas ${ }^{49}$ (fig. 19).

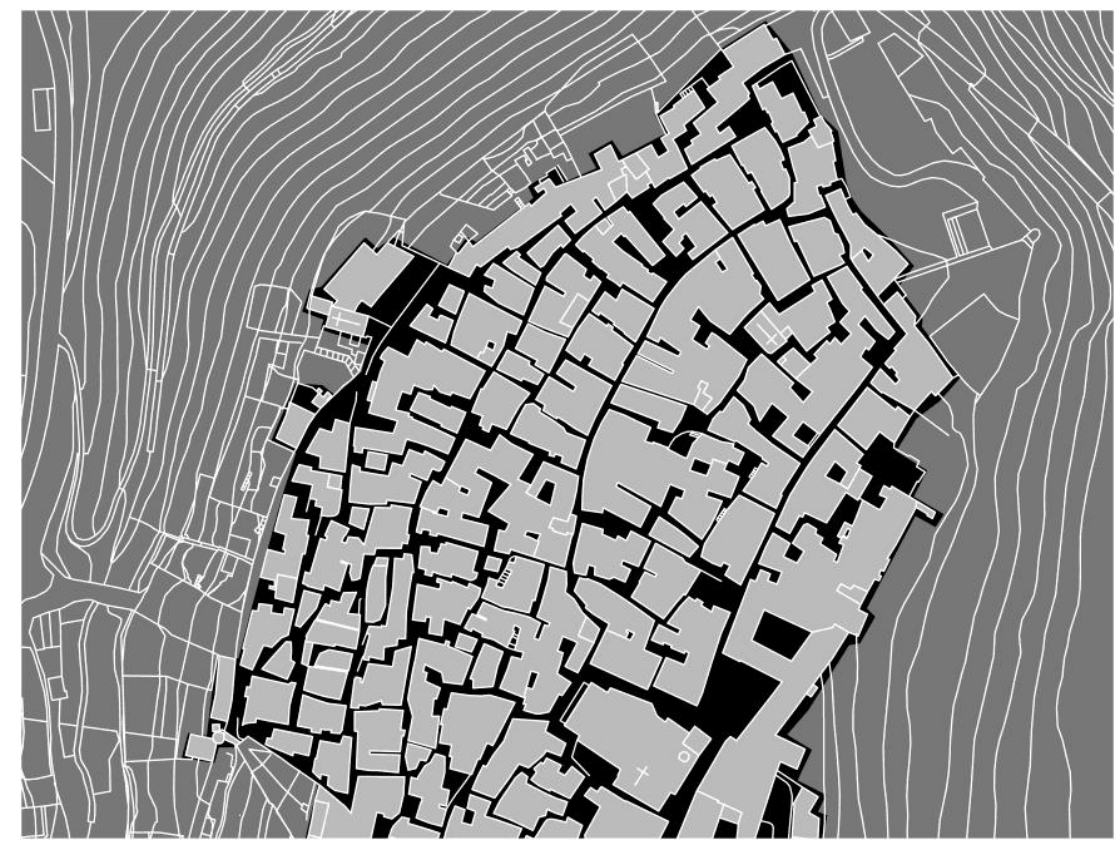

Fig. 19. The urban structure of the Saracena and Rabata quarters of Tricarico.

\footnotetext{
42 In this regard: Musca 1964.

43 Pedio 1968: 20-21.

44 Serra 1983: 2-3.

45 Serra 1983: 6.

46 Graziadei 2008: 53-54.

47 Montesano 2004: 33-42.

48 Colletta 1992: 202.

49 Guidoni, 1979: 578. They are, however, characters which, alone, without other references such as place names, not necessarily refer to a specific settlement culture (Graziadei, 2008: 54-55).
} 
If a large part of the army sent by the Caliph 'Umar to the conquest of North Africa was made up of farmers from Yemen ${ }^{50}$, the presence of elements of Yemeni origin in the 'Ifrīqiya and in southern Italy does not surprise. The emir of Bari himself, Sawdān alMāwrī, would probably be from the region of the Tihāma, as many members of the aghlabide $a r m y^{51}$. These circumstances may suggest opportunities for exchange between local and eastern knowledge systems. The same circumstances could justify common matrices between certain ways of organising the gardens of Tricarico and the ways of managing agricultural areas and water resources used in Yemen and Al-Andalus, - the latter also with a significant Yemeni settlement at that time ${ }^{52}$.

However, if the described agricultural land and devices refer, for their structures and functioning, to the South Arabian or Islamic world, their implant in Tricarico by Arab and Berber populations from North Africa or Sicily between the ninth and eleventh centuries is not granted. The sources used for the preparation of this paper and, among other things, in the absence of an archaeological investigation, do not allow unambiguous attribution of the described structures to these ethnic groups, nor do they allow speculating on valid dates.

A derivation of the systems from Islamic and, later, Christian Spain, as was the case for North Africa and the Americas ${ }^{53}$, cannot be ruled out. In this process, the various groups of Jews from Spain, settled in Tricarico during the fifteenth century ${ }^{54}$ may have played a role.

\section{Conclusions}

Whether or not they are the product of the Arab and Berber presence, or they simply derive from autonomous forms of adaptation and exploitation of certain environmental conditions, the farming systems of Tricarico are the result of a complex system of knowledge and practices that, over the centuries, have given shape to the natural resources, transforming them into expressions of culture. The enormous job of producing the described physical spaces and devices proceeded hand in hand with the formation and sedimentation of intangible heritage related to the know-how and perfectly clear still today in the way of managing the gardens of Tricarico, albeit with adaptations to different needs and through the use, at times, of modern materials and tools.

The one visible today is a cultural landscape of great value but is also a great living archive of know-how, practices and skills managed and renewed day after day by determined and laborious people. Its preservation needs good understanding both of the physical features and the knowledge that produced it and made it work. And still makes it work today.

Acknowledgments. I would like to express my gratitude to Arch. Pietro Laureano for introducing me to the gardens of Tricarico and for giving me precious research ideas. I

\footnotetext{
50 Kennedy 2008: 142.

51 Di Branco 2011: 7.

52 Kirchner 2003: 151; Barceló 2004: 44-50, 116.

53 Glick 1970: 176.

54 Colafemmina 1983: 111, 113.
} 
must also thank Arch. Antonio Infantino for his valuable suggestions and encouragement. Thanks to Arch. Gerardo Sassano who helped me in producing the drawings. A special thank goes out to all the farmers of Tricarico who shared with me their extraordinary knowledge: I will always be thankful to them.

\section{References}

Al-Ghulaibi, N. M. A. (2008): Traditional Water Harvesting on the Mountain Terraces of Yemen, in Z. Adeel, B. Schuster, H. Bigas, Eds., What Makes Traditional Technologies Tick? A Review of Traditional Approaches for Water Management in Drylands, UNU-INWEH, pp. 21-35.

Barceló, M., Kirchner, H., Torró, J. (2000): Going around Zafār (Yemen), the Banū Rucayn field survey: hydraulic archaeology and peasant work, Proceedings of the Seminar for Arabian Studies, 30: 27-39.

Barceló, M. (2004): Los Banū Rúayn en Al-Andalus, Granada, A-Baraka.

Biscaglia, C. (1999-2000): Presenze e permanenze arabo-nusulmane a Tricarico, Bollettino Storico della Basilicata, 15-16: 107-112.

Biscaglia, C. (2003/a): Il Liber iurium della città di Tricarico. Introduzione: origine e sviluppo di un municipio del Merzogiorno d'Italia nei secoli XIV-XVI: società, vita politico-amministrativa, gestione del territorio, economia, cultura, rapporti col potere signorile, t. I, Galatina, Congedo.

Biscaglia, C. (2003/b): Il Liber iurium della città di Tricarico. Edizione, t. II, Galatina, Congedo.

Biscaglia, C. (2012): Incursioni arabe in Basilicata. La Saracena e la Rabata di Tricarico, i giardini e gli idiomi linguistici, Basilicata Regione Notizie, 129-130: 77-95.

Braun, G., Hogemberg, F. (1618): Tricaricum Basilicatae civitas, Theatrum Urbium praecipuarum mundi, VI, Köln, pl. 57.

Carbonero Gamundi, M. A. (1984): Terrasses per al cultiu irrigat i distribució social de l'aigua a Banyalbufar (Mallorca), Documents d'Anàlisi geogräfica, 4: 31-68.

Colafemmina, C. (1983): Documenti per la storia degli Ebrei a Tricarico nei secc. XV-XVI, Studi Storici Meridionali, III (1-2): 111-126.

Colletta, T. (1992): Tradizione urbanistica islamica e centri campani: un problema di storigorafia urbana, in A. Cilardo, Ed., Atti del convegno sul tema. Presenza araba e islamica in Campania, pp. 197-207.

De Martino, E. (1950): Note Lucane, Società, VI (4): 650-667.

Di Branco, M. (2011) Due notizie concernenti l'Italia meridionale dal Kitāb al-'uyūn wa 'lhadā'iq fì ahbār al-ḥaqā'iq (Libro delle fonti e dei giardini riguardo la storia dei fatti veridici), Archivio storico per la Calabria e la Lucania, LXXVII, 5-13. 
Fascetti, S. (2012): Orti saraceni a Tricarico. Un progetto di rivalutazione, Basilicata Regione Notizie, 129-130: 97-107.

Glick, T. F. (1970): Irrigation and society in medieval Valencia, Cambridge (Ma.), Belknap.

Glick, T. F. (1995): From Muslim fortress to Christian castle. Social and cultural change in medieval Spain, Manchester, Manchester University Press.

Glick, T. F., Kirchner, H. (2000): Hydraulic Systems and Technologies of Islamic Spain: History and Archaeology, in P. Squatriti, Ed., Working with Water in Medieval Europe: Technology and Resource-Use, Brill, pp. 267-330.

Graziadei, A. (2004): Appunti sul rapporto tra risorse naturali ed insediamenti antropici in Basilicata, Melfi, Libria.

Graziadei, A. (2008): La componente urbanistica di matrice islamica nella Rabata di Pietrapertosa (Potenza), Bollettino Storico della Basilicata, 24: 49-61.

Guidoni, E. (1979): La componente urbanistica islamica nella formazione delle città italiane, in F. Gabrieli, U. Scerrato, Eds., Gli Arabi in Italia, Milano, Scheiwiller, pp. 575598.

Harrower, M. J. (2008): Hydrology, Ideology, and the Origins of Irrigation in Ancient Southwest Arabia, Current Anthropology, 49 (3): 497-510.

Insetti, M. I. (2013): Gli orti Saraceni di Tricarico. La progettazione di un Parco ecologicoletterario, Basilicata Regione Notizie, 131-132: 180-189.

Kennedy, H. (2008): Le grandi conquiste arabe, It. tr., Roma, Newton Compton (Weidenfeld \& Nicolson, 2007).

Kirchner, H. (2003): Majiji: a type of hydraulic system in Yemen and in al-Andalus? in Proceedings of the Seminar for Arabian Studies, 33, Archaeopress, pp. 143-155.

Kirchner, H. (2010): Arqueologia hidràulica i tipologia d'espais irrigats andalusins, in F. Sabaté, Ed., III Curs Internacional d'Arqueología Medieval. La prospecció i el territori, Pagès, pp.129-146.

Laureano, P. (1988): Sahara: giardino sconosciuto, Firenze, Giunti.

Laureano, P. (2001): Atlante d'acqua. Conoscenze tradiz̧ionali per la lotta alla desertificażione, Torino, Bollati Boringhieri.

Laureano, P. (2004): I terrazzamenti del territorio Campano, in La cultura dei terrazzamenti per la salvaguardia del paesaggio: tecniche, risorse, strumenti, Menabò, pp. 84-97.

Lavecchia, M., Macaione, I. (2007): Il Parco ecologico-letterario degli Orti Saraceni, in I. Macaione, Ed., Architettura e management della città-natura, Franco Angeli, pp. 87-124.

Montesano, N. (2004): Tursi. Alle radici del toponimo Rabatana, in C. D. Fonseca, Ed., Tursi. La Rabatana, Altrimedia, pp. 33-42. 
Musca, G. (1964): L'emirato di Bari 847-871, Bari, Dedalo.

Navarro, C. (1995): El ma'gil de Liétor: un sistema de terrazas de origen andalusí en activo, in I Congreso de Arqueología Peninsular, Fundación Rei Alfonso Henriques, VI, pp. 365-378.

Pedio, T. (1968): I paesi lucani nell'alto medioevo, in T. Pedio, Ed., Fortunato, G., Badie, Feudi e Baroni della V alle di Vitalba, Lacaita, pp. 9-25.

Robin, C., Dridi, H. (2004): Deux barrages du Yémen antique (note d'information), Comptes rendus des séances de l'Académie des Inscriptions et Belles-Lettres, CXLVIII (1): 67-121.

Ron, Z (1966/a): Agricultural Terraces in The Judean Mountains, Israel Exploration Journal, 16 (1): 33-49.

Ron, Z (1966/b): Agricultural Terraces in The Judean Mountains, Israel Exploration Journal, 16 (2): 111-122.

Ron, Z. Y. D. (1985): Developments and management of irrigation systems in mountain regions of the Holy Land, Transactions of the Institute of British Geographers New Series, 10 (2): 149-169.

Serra, L. (1983): Sopravvivenze lessicali arabe e berbere in un'area dell'Italia meridionale: la Basilicata, Napoli, Istituto Universitario Orientale.

Trillo San José, C. (2003): Agua y paisaje en Granada. Una herencia de Al-Andalus, Granada, Diputación de Granada.

Varisco, D. M. (1983): Irrigation in an Arabian Valley. A System of Highland Terraces in the Yemen Arab Republic, Expetition, 25 (2): 26-34. 